\title{
LUDEP 1.0, un logiciel pour ordinateur personnel qui applique le nouveau modèle pulmonaire de la CIPR*
}

\author{
N.S. JARVIS**, A. BIRCHALL**
}

RÉSUMÉ La Commission internationale de protection radiologique a récemment approuvé un nouveau modèle pour la dosimétrie des voies aériennes. Ce modèle a été conçu pour décrire le plus fidèlement possible l'incorporation, le dépôt et le devenir biocinétique des radionucléides inhalés, et pour calculer les doses délivrées à l'appareil respiratoire. Un logiciel, basé sur le nouveau modèle, a été développé pour faciliter l'application pratique des nouvelles recommandations, et permettre d'en évaluer les conséquences radiologiques pour le poumon et les autres organes. LUDEP 1.0 (LUng Dose Evaluation Program) est un programme convivial pour ordinateur PC compatible IBM qui permet à son utilisateur de calculer les doses délivrées à l'appareil respiratoire et, secondairement, aux autres organes.

ABSTRACT The International commission on radiological protection has recently approved a new model of the human respiratory tract. This model has been designed to represent realistically the deposition and biokinetic behaviour of inhaled radionuclides, and to calculate doses to the respiratory tract. In order to examine the practical application and radiological implications of the new model, a personal computer program has been developed. LUDEP 1.0 (LUng Dose Evaluation Program) is a user-friendly program for the IBM-compatible PC which enables the user to calculate doses to the respiratory tract and to other organs.

Le programme, décrit ci-dessous, existe en deux versions, une version anglaise NRPB-SR264 créée par les auteurs et une version française NRPBSR264 (F) adaptée par les auteurs en collaboration avec J.L. Malarbet*** et M. Roy***.

\footnotetext{
* Communication présentée au Workshop "Intakes of Radionuclides", Bath, 13-17 septembre 1993.

** Pour tous renseignements commerciaux, s'adresser au NRPB, Chilton, Didcot, OX11 ORQ, Grande Bretagne.

*** Commissariat à l'énergie atomique, Institut de protection et de sûreté nucléaire (IPSN/DPHD/SDOS), BP 6, 92265 Fontenay-aux-Roses Cedex, France.
} 


\section{Introduction}

The International commission on radiological protection (ICRP) has recently approved a new model of the human respiratory tract (ICRP Publication 66) [5]. The main difference from the ICRP Publication 30 model [2] is that the new model has been designed to represent realistically the deposition of inhaled particles in the respiratory tract, the subsequent clearance of the deposited radionuclides, and the doses to each region of the respiratory tract. The model is necessarily more complicated than its predecessor, and deposition, clearance, and dosimetry are treated in more detail.

LUDEP was developed in collaboration with members of the ICRP Task group that developed the model as an aid in examining the model predictions of clearance and retention, and by determining the implications of the model regarding dosimetry. It was also of use in confirming the practicality of implementing the model.

\section{Description of LUDEP}

LUDEP is a suite of programs, each developed in Turbo Basic and compiled for the IBM-compatible personal computer (IBM is a registered trademark of International business machines corporation).

It enables the user to calculate doses and dose rates to the respiratory tract regions and other body organs for a wide range of user-defined conditions. The software has been designed to be as flexible as possible, permitting the user to change most of the parameters used in the dose calculation and display the results obtained at each stage of the calculation.

In the majority of situations, the user will wish to use ICRP-recommended parameter values, and so LUDEP selects these default values automatically when loaded.

The program has a modular form, with each module called automatically by a central program, over which the user has direct control. The main menu screen is shown in Figure 1. The upper part of the screen contains the menu for selecting the modules which enable the various parameters to be specified and the dose calculations to be performed ; the lower part of the screen displays the values of several of the important parameters already chosen by the user.

In a typical dose calculation, the user selects modules from the main menu, starting with the uppermost option and working downwards. The parameters are entered using the first seven options, described below. 
LUDEP 1.0, UN. LOGICIEL POUR ORDINATEUR PERSONNEL

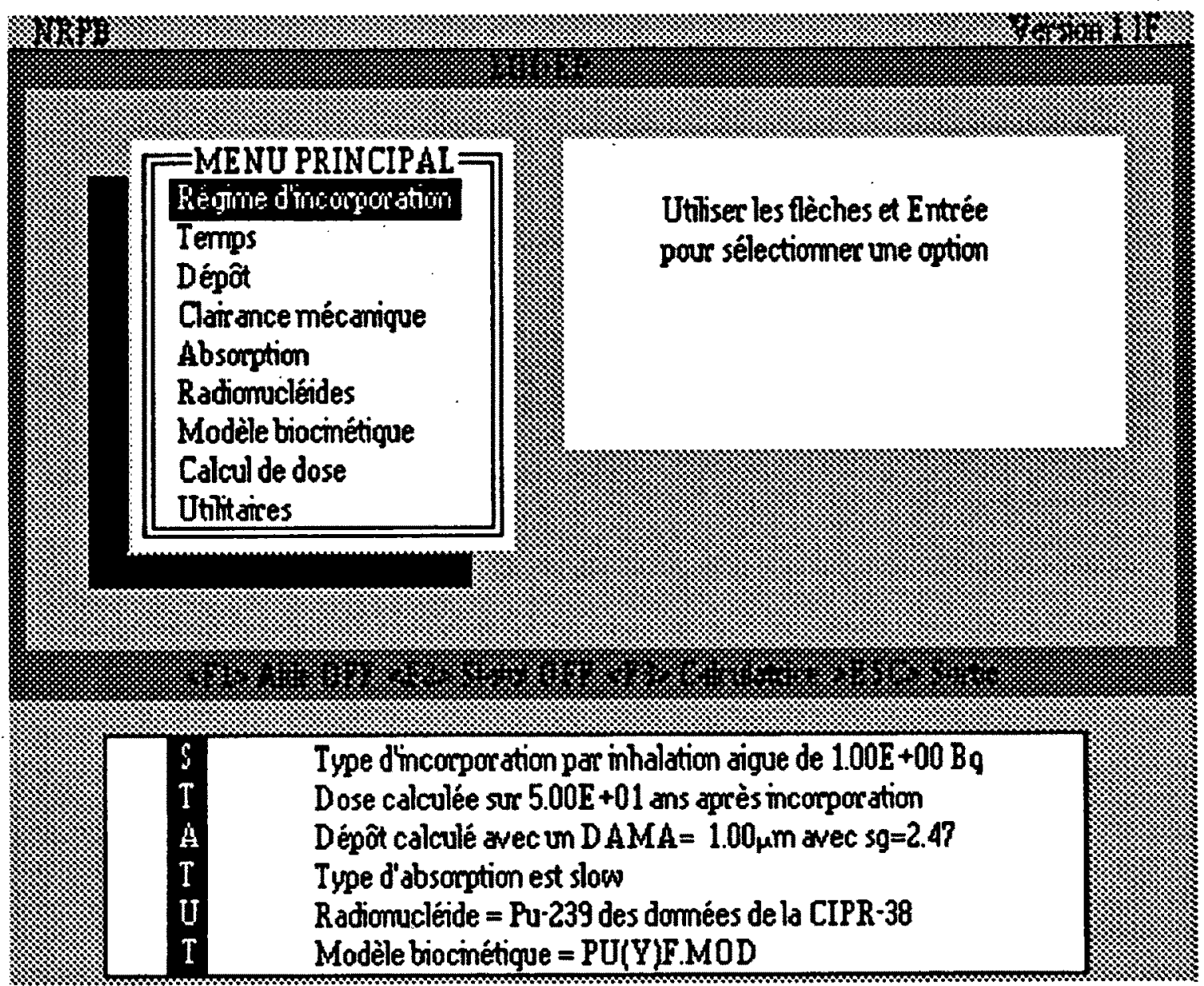

Fig. 1. - The main menu screen in LUDEP 1.1F (french version).

In the first option, intake regime, details of the intake or exposure to the radionuclide are entered. In the second, time, the user enters the time at which the dose rate or cumulative dose is calculated. In deposition, the fractional deposition in each region of the respiratory tract can be specified directly, or calculated from specific particle size parameters and/or physiological parameters. In particle transport, the rates at which deposited particles move from one region of the respiratory tract to another, and the rates at which particles are cleared from the respiratory tract, can be altered. In absorption, the rates of particle dissolution and subsequent uptake to blood are specified. Radionuclides enables the radionuclide of interest to be selected from one of two databases. The first incorporates decay data from ICRP Publication 38 [3], and is recommended to the user. The second is included to permit comparison. Biokinetic model allows the user either to enter a biokinetic model directly or to select one of the models specified in ICRP Publication 30 [2].

The eigth option, dose calculation, calculates the doses or dose rates to the regions of the respiratory tract and to the body organs, using an internal database of specific absorbed fractions for photons. The user can select either the ICRP Publication 26 tissue weighting factors [1], or those given in ICRP 
Publication 60. [4]. The final menu option, ludep utilities, contains some useful facilities, including those for saving all the parameters into a disk file and entering the DOS environment with LUDEP stored in memory.

\section{Mathematical methods used by LUDEP}

In ICRP Publication 66 [5] the deposition of a monodisperse aerosol in the different regions of the respiratory tract is modelled by treating the regions as a series of filters. ICRP Publication 66 gives an algebraic expression for the deposition efficiency in each region, which depends on both the thermodynamic and the aerodynamic diameters of the particles. LUDEP implements these equations directly for monodisperse aerosols, and treats polydisperse aerosols as a convolution of 100 monodisperse aerosols of appropriate sizes.

The LUDEP dose calculation module combines the respiratory tract model with the ICRP gastrointestinal tract model and the biokinetic models to form one large non-recycling compartment model. The deposition fractions are combined with the intake to determine the initial number of atoms in each compartment. The remaining activity and integrated disintegrations in each compartment are then calculated using a very fast algorithm, which was designed specifically for the solution of non-recycling models.

Dosimetry for body organs is treated in the conventional manner. First, the dose to each of 25 target organs from unit disintegration in each source organ is calculated by combining information for the specific radionuclide with the appropriate absorbed fractions to form a matrix of specific effective energy (SEE) values. The SEE matrix is then multiplied by the array containing the number of disintegrations in each source organ to give the dose to each target organ. Dosimetry of the respiratory tract is treated by using algebraic approximations for the energy-dependent absorbed fractions from the various subregions of the respiratory tract to the sensitive cells.

\section{Quality assurance}

The deposition parameters and equations used in LUDEP were systematically checked against ICRP Publication 66; the tables of deposition values given in ICRP Publication 66 were actually derived from calculations made with LUDEP. The values of other parameters contained in LUDEP have been checked against their source documents - these are tabulated in the report NRPB-R264 [6]. The biokinetic model database and the biokinetic calculations in the program were validated by comparing the disintegrations and organ doses calculated by LUDEP for ingested radionuclides with those in ICRP Publication 30 [2]. Organ doses were also compared with those in NRPBGS7 [7]. The database of radionuclide decay data from ICRP Publication 38 [3] was compiled directly from the text files used in the creation of ICRP 
Publication 38. The entries in the database were verified for several radionuclides. The file containing the database of absorbed fractions was also taken directly from those used in creating the original source document. The equations giving the absorbed fractions for the respiratory tract tissues as a function of energy were taken directly from the software used by ICRP to generate them, and the values in the tables of absorbed fractions in ICRP Publication 66 were calculated using LUDEP. Finally, checks were made of the model solution and dosimetry by independent parties forming their own implementations of the lung model and comparing their results with those of LUDEP.

\section{Hardware requirements}

A hard disk drive with $1.6 \mathrm{MB}$ of available storage space is required to install LUDEP and the associated databases. The software will run on any standard IBM PC, AT, XT or true compatibles $(8086,80286,80386$ or 80486 ) with MS-DOS 3.0 or later; however, because the calculations are very complicated, an arithmetic co-processor is highly recommended (8087, 80287 or 80387$)$. The program automatically detects the presence of a co-processor and uses it if present. The RAM required to run LUDEP is $532 \mathrm{kB}$. A VGA colour monitor is also recommended if the user wishes to view all of the diagrams.

\section{Availability of the two versions of LUDEP}

The executable code for LUDEP 1.0 has been published by NRPB as the software package NRPB-SR264 [6]. The French version, LUDEP 1.1F, will be published as NRPB-SR264(F), and available from NRPB Technical publications. The charge made for the package is to cover the extra work entailed by making it commercially available, and not the development costs.

Further versions of LUDEP are under development, since there are many additional capabilities which would be useful. For example, in LUDEP 1.0 or $1.1 \mathrm{~F}$, it is not, in general, possible to include the contribution to dose from the radioactive progeny of a selected radionuclide. It would also be useful to predict urinary and faecal excretion rates and carry out other calculations useful for bioassay interpretation. It is intended that improved methods of dealing with all radioactive daughters and bioassay calculations will be included in a future version of LUDEP. Furthermore, it is intended that, as the models and methods employed in radiological protection are refined or changed, these will be incorporated in successive versions of the program.

Acknowledgements : This work is partially funded by CEC within the CEC/NRPB association agreement under contract F13PCT920064a. 


\section{REFERENCES}

[1] INTERNATIONAL COMMISSION ON RADIOLOGICAL PROTECTION (ICRP). - Recommendations... (ICRP publication 26). Ann. ICRP, 1977, 1 (3). (version française Oxford: Pergamon press).

[2] INTERNATIONAL COMMISSION ON RADIOLOGICAL PROTECTION (ICRP). - Limits for intake of ranionuclides by workers (ICRP publication 30). Pt 1. Ann. ICRP, 1979, 2 (3/4) ; Pt 2. Ann. ICRP, 1980, 4 (3/4) ; Pt 3. Ann. ICRP, 1981, 6, (2/3) ; Pt 4. Ann. ICRP, 1988, 19 (4).

[3] INTERNATIONAL COMMISSION ON RADIOLOGICAL PROTECTION (ICRP). - Radionuclide transformations: energy and intensity of emissions (ICRP publication 38). Ann. ICRP, 1983, 11-13.

[4] INTERNATIONAL COMMISSION ON RADIOLOGICAL PROTECTION (ICRP). - Recommendations... (ICRP publication 60). Ann. ICRP, 1991, 21 (1/3) (version française Oxford : Pergamon press, 1993).

[5] INTERNATIONAL COMMISSION ON RADIOLOGICAL PROTECTION (ICRP). - Human respiratory tract model for radiological protection (ICRP publication 66). Ann. ICRP, 1994, 24 (1/4) (in press).

[6] BIRCHALL A., JARVIS N.S., BAILEY M., DORRIAN M. - Implementation of the new ICRP human respiratory tract model : LUDEP 1.0 (NRPB-SR264). Londres : HMSO, 1994.

[7] KENDALl G., KENNEDY B., GREENHALGH J., ADAM N., FELL T. Committed dose equivalent to selected organs and committed effective dose equivalent from intakes of radionuclides (NRPB-GS7). Londres: HMSO, 1987. 